Section Editor

Mitchell S.V. Elkind, MD, MS

\title{
Teaching NeuroImages: \\ Reversible widespread brain MRI lesions in Marchiafava-Bignami disease
}

Irena Dujmović, MD, $\mathrm{PhD}$

Ivan Nikolić, MD

Mira Gavrić-Kezić, MD

Jelena Dačković, MD

Šarlota Mesaroš, MD,

$\mathrm{PhD}$

Jelena Drulović, MD,

$\mathrm{PhD}$

Correspondence to

Dr. Dujmović:

irdujm@EUnet.rs

Download teaching slides: Neurology.org

Figure T2-weighted (T2W), fluid-attenuated inversion recovery (FLAIR), and diffusion-weighted (DWI) brain MRIs in Marchiafava-Bignami disease

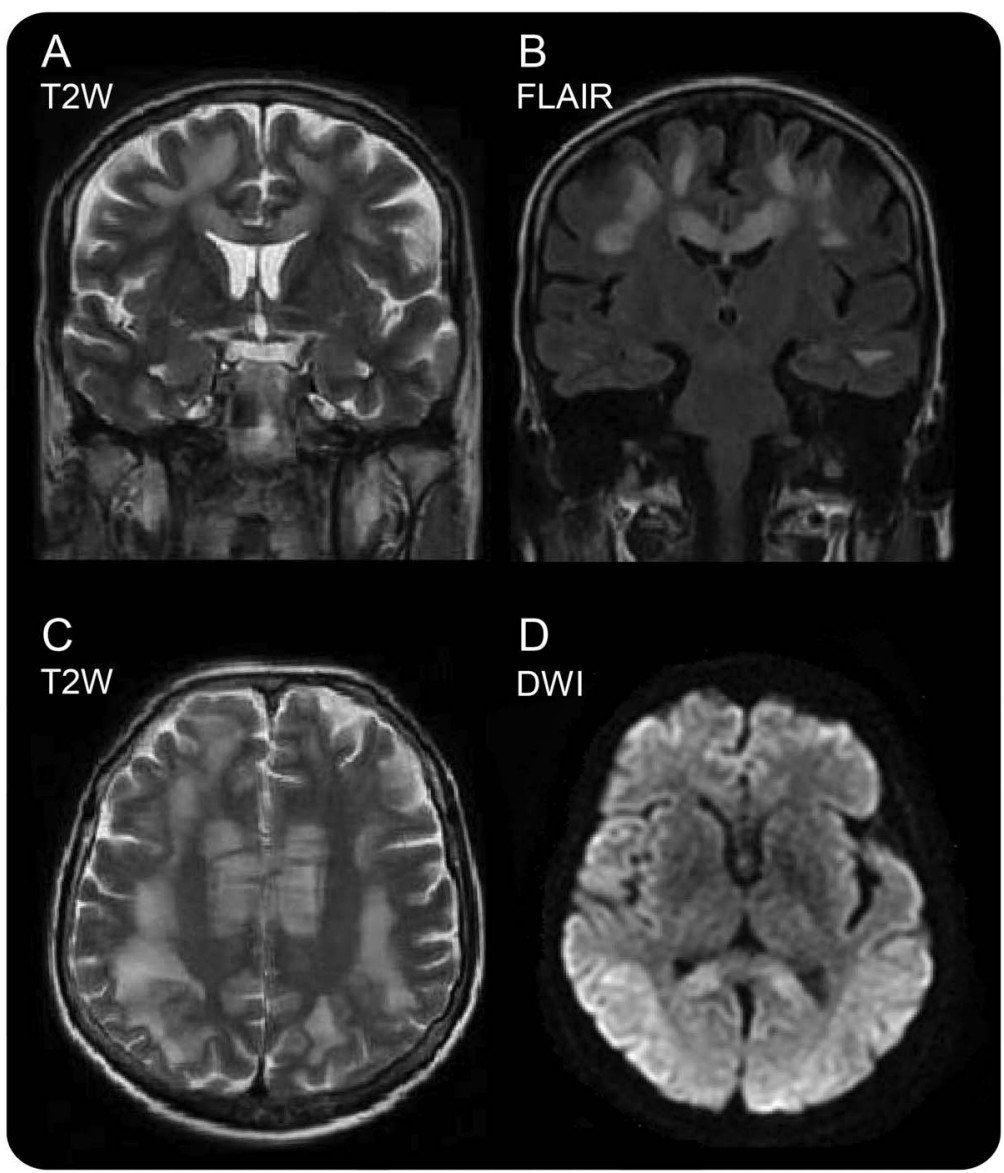

(A-C) Corpus callosum hyperintensity and diffuse swelling with extensive extracallosal hyperintense white matter lesions. (D) Bilateral cortical and white matter hyperintensity involving splenium of the corpus callosum.

A 54-year-old woman with a history of alcoholism presented with stupor. Brain MRI disclosed extensive callosal and widespread extracallosal white matter and cortical lesions (figure) suggestive of MarchiafavaBignami disease (MBD). ${ }^{1}$ After 4 weeks of treatment with thiamine and corticosteroids, a complete resolution of brain MRI lesions along with a good clinical recovery was observed.

In MBD, which is rare and frequently associated with alcoholism, brain MRI may show callosal, but

From the Clinic of Neurology (I.D., J. Dačković, S.M., J. Drulović) and MRI Centre (I.N.), Clinical Centre of Serbia, Belgrade; University of Belgrade School of Medicine (I.D., S.M., J. Drulović), Serbia; and County Hospital (M.G.-K.) Užice, Serbia.

Go to Neurology.org for full disclosures. Funding information and disclosures deemed relevant by the authors, if any, are provided at the end of the article. also extracallosal, white matter and cortical lesions. ${ }^{1,2}$ In alcoholic MBD patients with impaired consciousness, rapid resolution of the widespread callosal, extracallosal, and cortical MRI lesions is highly unusual. $^{1,2}$

\section{AUTHOR CONTRIBUTIONS}

Dr. Dujmović: drafting/revising the manuscript for content, study concept or design, analysis/interpretation of data. Dr. Nikolić: drafting/ revising the manuscript for content, analysis/interpretation of data, acquisition of data. Dr. Gavrić-Kezić: drafting/revising the manuscript for 
content. Dr. Dačković: drafting/revising the manuscript for content. Dr. Mesaroš: drafting/revising the manuscript for content. Dr. Drulović: drafting/revising the manuscript for content, study concept or design, analysis/interpretation of data.

\section{STUDY FUNDING}

Supported by the Republic of Serbia Ministry of Education, Science and Technological Development (Grant No 175031).

\section{DISCLOSURE}

I. Dujmović has been supported by the Republic of Serbia Ministry of Education, Science and Technological Development (Grant No 175031). I. Nikolić, M. Gavrić-Kezić, and J. Dačković report no disclosures. S. Mesaroš has been supported by the Republic of Serbia Ministry of Education, Science and Technological Development
(Grant No 175031). J. Drulović has been supported by the Republic of Serbia Ministry of Education, Science and Technological Development (Grant No 175031). Go to Neurology.org for full disclosures.

\section{REFERENCES}

1. Hillbom M, Saloheimo P, Fujioka S, Wszolek ZK, Juvela S, Leone MA. Diagnosis and management of MarchiafavaBignami disease: a review of CT/MRI confirmed cases. J Neurol Neurosurg Psychiatry 2014;85:168-173.

2. Ménégon P, Sibon I, Pachai C, Orgogozo JM, Dousset V. Marchiafava-Bignami disease: diffusion-weighted MRI in corpus callosum and cortical lesions. Neurology 2005;65: 475-477. 


\section{Neurology}

\section{Teaching NeuroImages: Reversible widespread brain MRI lesions in Marchiafava-Bignami disease \\ Irena Dujmovic, Ivan Nikolic, Mira Gavric-Kezic, et al. \\ Neurology 2015;84;e81-e82 \\ DOI 10.1212/WNL.0000000000001373}

\section{This information is current as of March 16, 2015}

\section{Updated Information \& Services}

Supplementary Material

\section{References}

Subspecialty Collections

Permissions \& Licensing

Reprints including high resolution figures, can be found at: http://n.neurology.org/content/84/11/e81.full

Supplementary material can be found at: http://n.neurology.org/content/suppl/2015/03/15/WNL.0000000000001 373.DC1

This article cites 2 articles, 2 of which you can access for free at: http://n.neurology.org/content/84/11/e81.full\#ref-list-1

This article, along with others on similar topics, appears in the following collection(s):

Alcohol

http://n.neurology.org/cgi/collection/alcohol DWI

http://n.neurology.org/cgi/collection/dwi

MRI

http://n.neurology.org/cgi/collection/mri

Prognosis

http://n.neurology.org/cgi/collection/prognosis

Information about reproducing this article in parts (figures,tables) or in its entirety can be found online at:

http://www.neurology.org/about/about_the_journal\#permissions

Information about ordering reprints can be found online:

http://n.neurology.org/subscribers/advertise

Neurology ${ }^{\circledR}$ is the official journal of the American Academy of Neurology. Published continuously since 1951 , it is now a weekly with 48 issues per year. Copyright @ 2015 American Academy of Neurology. All rights reserved. Print ISSN: 0028-3878. Online ISSN: 1526-632X.

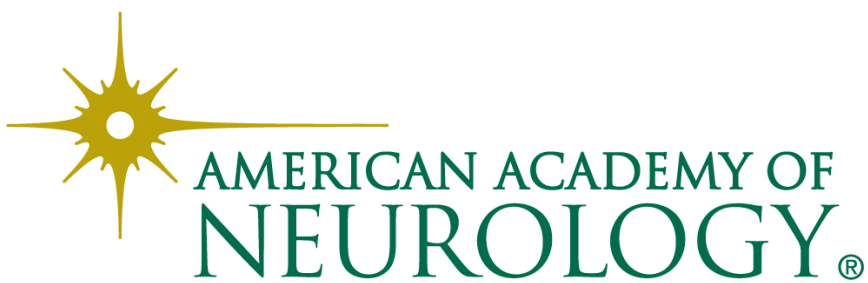

